(C) Inra/Elsevier, Paris

Original article

\title{
The morphological characteristics, root growth potential and flushing response of rooted cuttings compared with transplants of Sitka spruce
}

\author{
Conor O'Reilly*, Charles Harper \\ Department of Crop Science, Horticulture and Forestry, Faculty of Agriculture, \\ University College Dublin, Belfield, Dublin 4, Ireland
}

(Received 13 March 1998; accepted 13 October 1998)

\begin{abstract}
The morphological and some physiological attributes of Sitka spruce (Picea sitchensis (Bong.) Carr) rooted cuttings derived from juvenile selections in the nursery were compared with those of conventional unimproved transplants grown in Ireland in 1996 and 1997. A field trial was established in the second year to assess flushing and growth responses of the stock. Although some were highly significant, absolute differences between stock types in most morphological characteristics were small. Cuttings had much fewer branches/cm shoot, and root dry weights were smaller than in transplants, but the shoot/root ratio differed little between stock types. The root growth potential (RGP) of cuttings was good, but was lower than that of the transplants in 1997 but not in 1996 . Cuttings flushed 3-5 days earlier than the transplants in the RGP tests, and up to 10 days earlier in the field trial. The earlier flushing of the cuttings probably occurred largely because the cuttings were derived from material selected for having rapid juvenile growth rates. The height increment of cuttings was greater than that of transplants after one growing season in the field. (C) Inra/Elsevier, Paris.)
\end{abstract}

vegetative propagation / plant quality / Sitka spruce

Résumé - Caractéristiques morphologiques, capacité de croissance racinaire, débourrement et croissance comparés de boutures racinées et de semis repiqués d'épicéa de Sitka Sur épicéa de Sitka (Picea sitchensis (Bong.) Carr), des boutures racinées issues de sélections juvéniles en pépinière ont été comparées à des plants repiqués classiques non améliorés génétiquement. Effectuée en Irlande en 1996 puis en 1997, cette comparaison a porté sur des critères morphologiques et physiologiques. De plus, un dispositif en plantation a été installé en 1997 pour suivre le débourrement et la croissance des deux types de plant. Bien que parfois hautement significatives, les différences observées sur la plupart des critères morphologiques étaient faibles. Cependant, par rapport aux plants repiqués, les boutures avaient beaucoup moins de branches par $\mathrm{cm}$ de tige, leur masse sèche racinaire était plus faible, mais le rapport des masses «tige/racines » variait peu entre les deux types de plant. La capacité de croissance racinaire des boutures était bonne, à un niveau semblable à celle des plants repiqués en 1997, mais inférieur en 1996. Le débourrement des boutures a été plus précoce que celui des plants repiqués, la différence de 3 à 5 j en test de régénération racinaire allant jusqu'à 10 j sur le dispositif de plantation. Le débourrement plus précoce des boutures est probablement lié à la sélection du matériel végétal de base sur la croissance juvénile. La croissance des boutures un an après plantation était effectivement supérieure à celle des plants repiqués non améliorés. (ㅇ) Inra/Elsevier, Paris.)

multiplication végétative / boutures / qualité des plants / Picea sitchensis / type de plant

\footnotetext{
* Correspondence and reprints

Conor.oreilly@ucd.ie
} 


\section{INTRODUCTION}

Sitka spruce (Picea sitchensis (Bong) Carr) is the most important commercial tree species in Ireland, and is the only one for which there is a relatively advanced tree breeding programme. It is estimated that gains of $10 \%$ or more in volume increment could be realised by using genetically improved Sitka spruce compared with conventional planting stock (data on file, Coillte Teo. (Irish Forestry Board)). The use of vegetatively propagated material is likely to be an important vehicle for delivering the genetically improved planting stock into use [36, 47].

The use of vegetative propagation methods allows the production of a much larger quantity of planting stock than would otherwise be possible from the scarce resource of improved seeds. A potential total of about 500 rooted cuttings can be produced from one seed [18], spreading the cost of the seeds over many plants. Sufficient quantities of improved seeds cannot be produced to satisfy the demand for planting stock in Ireland, even if multiplied using vegetative propagation techniques. For this reason, it is likely that a significant proportion of the cuttings will continue to be derived from early selections of juvenile material in the nursery, using a method similar to that described by Kleinschmit [20].

In Ireland, Coillte Teo. have established a vegetative propagation facility for Sitka spruce which will produce about one million cuttings per annum. At present all cuttings are derived from juvenile selections. Field trials have been established to assess the performance of cuttings, and early results appear promising (data on file, Coillte Teo.). To encourage the use of cuttings in operational forestry, information on the quality of the planting stock raised from cuttings is warranted. In one study in the US using coastal Douglas fir (Pseudotsuga menziesii (Mirb.) Franco), differences in dormancy intensity and some morphological variables between cuttings and conventional stock were detected, the cuttings tending to be of slightly superior quality [40]. Similarly, differences in morphology between cuttings and conventional stock of loblolly pine (Pinus taeda L.) were small [13]. The morphological quality of cuttings of Norway spruce Picea abies (L.) Karst have also been studied $[19,21]$, and some differences between the stock types have been detected [19].

A preliminary study [27] indicated that there were differences in morphological characteristics, and in root growth potential and flushing response of rooted cuttings derived from selected material compared with unimproved transplants of Sitka spruce grown in Ireland. A follow-up study was carried out in 1996 and 1997 using material from another nursery to confirm these findings.
The results of the study provide useful practical information on several quality attributes of rooted cuttings currently being deployed in the operational programme in Ireland. However, the scientific conclusions are limited because of confounding effects. That is, the cuttings were derived from selected material, while the controls were unimproved transplants. Observed differences may reflect the effects of selection and propagation.

Several morphological variables, root growth potential and dormancy intensity of planting stock raised from rooted cuttings were assessed and compared with those of conventional transplants grown in the same nursery. Many investigators have found these attributes to be of key importance in determining field performance potential $[2,34,35,37,42,48]$. In the second year, a field trial was established also to evaluate potential differences between stock types in flushing times and in height increment.

\section{MATERIALS AND METHODS}

\subsection{Plant material}

All plant material was of similar origin in Washington (table I). The cuttings were derived from selections in the nursery (see below) over several years, and therefore originated from several provenances. The proportion of each provenance represented in the cuttings in this study is not known. The transplants used for comparison were unimproved material derived from seed collected from a single provenance, and this provenance was well represented also in the cuttings programme.

Because the cuttings were derived from selected material, the effects of propagation method were confounded with genetic differences between the stock types.

The selection procedure used to produce the vegetatively propagated material is similar to that described by Kleinschmit [20]. Three- or four-year-old transplants showing superior growth in the nursery were selected at an intensity of $1 / 50000$ to $1 / 100000$. The transplants were used to produce cuttings which were lined out in the nursery. In the next step, cuttings were taken only from the clones whose ramets were on average within the tallest $1 / 3$ of all clones. The cuttings were serially repropagated every 3 to 4 years to maintain juvenility.

The cuttings used for study were chosen from a crop destined for use in the field testing programme (as a prelude to use in the operational programme), while the transplants were conventional $2+1$ transplants from an adjacent section of the nursery. Cultural practices for both stock types in the bare-root nursery were the same, 
Table I. Identities of seeds used.

\begin{tabular}{lc}
\hline Transplants & Cuttings \\
\hline $6 / \mathrm{R} / 90-94(1996)$ & $6 / \mathrm{R} / 83-84,83-85,83-86,85-87$ \\
$6 / \mathrm{R} / 92(1997)$ & $\mathrm{HC} / 59 / 84-86$ \\
& $\mathrm{HC} / 2 / 84-88$ \\
& $105 / \mathrm{R} / 86-88$ \\
$6 / \mathrm{K} / 85-87$ \\
$94 / \mathrm{R} / 85-88$ \\
\hline
\end{tabular}

The seedlot used each year is indicated (in parentheses) for the transplants. The cuttings used each year were derived from all (bulked) seedlots indicated, but the proportion of each provenance included is not known.

and were similar to that described by Mason [25]. The procedure used to raise the cuttings in the propagation unit is similar to that described by Mason and Jinks [26]. After one season of growth in the propagation unit at the Coillte Nursery, Aughrim, Co. Wicklow $\left(52^{\circ} 27^{\prime} \mathrm{N}, 6^{\circ}\right.$ $29^{\prime} ; 100 \mathrm{~m}$ asl), the plants were lined out in the same nursery in the late summer/early autumn. The cuttings were grown for a further season in the nursery and then dispatched as 2-year-old bare-root planting stock.

\subsection{Sampling}

The plants used in this study were sampled from sections of the bed considered to be representative of the crop in the nursery at that time. On one occasion in February each year, 120 (1996) or 450 (1997) cuttings were lifted and dispatched for study, together with a similar number of transplants from an adjacent bed. For each stock type, plants were sampled from three locations within each section of the bed, then bulked by stock type for further study. The adjacent bed sections were approximately $30 \mathrm{~m}$ long. A larger number of plants was sampled in 1997 for use in the field trial. All plants were stored at $1-2{ }^{\circ} \mathrm{C}$ until all measurements/tests could be made.

\subsection{Observations, measurements and tests}

\subsubsection{Morphology}

The root collar diameter, plant height, current height increment, number of first- and higher-order branches were recorded for 60 plants of each stock type each year. Because cuttings do not have a true root collar, this measurement was taken just above the point of emergence of the uppermost root. After this, the dry weights of shoots, fibrous ( $<2 \mathrm{~mm}$ in diameter pre-drying, approx.), and woody roots $(>2 \mathrm{~mm}$ ) were determined after drying the samples at $65^{\circ} \mathrm{C}$ for $24 \mathrm{~h}$. New variables calculated from these data included: number of first-order and number of second-order branches per unit height, shoot/root dry weight ratio and shoot/fibrous root dry weight ratio.

\subsubsection{Root growth potential and days to bud burst in greenhouse}

Plants of each stock type were potted individually in $3.5 \mathrm{~L}$ pots containing a 3:1 (volume) mixture of peat/perlite. Twelve single pot replications of each stock type were placed on each of four benches in the greenhouse, for a total of 48 plants per stock type. Each bench was considered as a block. The two groups (subplots) of 12 pots were positioned at random within each block. The greenhouse was heated $\left(18-22{ }^{\circ} \mathrm{C}\right.$ day $/ 15-18{ }^{\circ} \mathrm{C}$ night $)$ and the photoperiod was extended to $16 \mathrm{~h}$ using high pressure sodium vapour lights. Relative humidity was maintained above $50 \%$ using time-controlled fine mist nozzles. The pots were watered to field capacity just after potting and at $2-3 \mathrm{~d}$ intervals thereafter. The number of plants per block having flushed lateral or terminal buds was recorded at $2-4 \mathrm{~d}$ intervals from the time that the first flushing lateral buds were noted. At the end of the trial 6 weeks after potting, the plants were removed from the pots and the roots washed in tap water. The number of new white roots $(>1 \mathrm{~cm})$ was recorded for each plant.

\subsubsection{7 field trial}

The field trial was established at the Coillte Teo., Tree Improvement Centre, Kilmacurra, Co. Wicklow (52 ${ }^{\circ} 56^{\prime}$ $\mathrm{N}, 6^{\circ} 09^{\prime} \mathrm{W}, 120 \mathrm{~m}$ asl). Plants of each stock type were dispatched for planting immediately after lifting in February, while the remainder were placed in the cold store $\left(1-2{ }^{\circ} \mathrm{C}\right)$. Plants were removed from the store and planted in mid March and in late April. The purpose of these later plantings was to determine if flushing differences would persist following longer periods of chilling. Increased chilling may reduce flushing response differences in conifers $[5,10]$. No attempt was made to elucidate the mechanism of this response.

The field trial was laid out as randomised block (four) split-plot design, each block containing one replicate of each of the six treatment combinations (two stock types $x$ three planting dates). Planting date was the main plot and stock type was the (split) subplot. Each subplot was a row containing about 20 plants. 
Beginning in late April, the number of plants having flushed lateral or terminal buds in each subplot was recorded at 2-3 d intervals until all plants had flushed, in early June. At the end of the growing season in November, the final height and height increment of each plant was measured. Height at planting was calculated by subtraction.

\subsection{Data analysis and presentation}

\subsubsection{Morphology}

All morphological data for plants other than those measured in the field trial were subjected to a $t$-test using the SAS software system [43]. Branch numbers were also analysed using the Mann-Whitney $U$ test because the data were not normally distributed [51].

\subsubsection{Root growth potential and days to bud burst}

The percentage of plants per block in each of the four blocks (12 plants each) having flushed terminal buds on each date was calculated for each stock type. The number of days to flushing of the first $50 \%$ of each stock type was interpolated (using a linear function) from these data. The flushing data were analysed as a split-plot design using the SAS [43] procedure to test for block and stock type effects. Because the variances of the RGP data were heterogeneous, the Kruskal-Wallis MannWhitney U test was used to evaluate the effects of stock type and block (separately) on RGP, also using the SAS software [43].

\subsubsection{Field growth responses}

For each treatment combination, the percentage of plants per replication having flushed lateral or terminal buds on each date was plotted versus (Julian) days, in a similar way to that already described for the greenhouse test. The date at which the first $50 \%$ of plants flushed was used in analysis and presentation. Similarly, final height, height at planting and height increment were analysed using block means for each variable. Height increment as a percentage of initial height was also used in the analyses because height at planting differed between stock types.

A factorial ANOVA following a randomised block, split-plot design was used to analyse all data using the SAS [43] procedure. The effects of blocks, planting date and stock type, and the interaction of planting date by stock type on these responses were tested. The mean square for the stock type by block interaction was also used as an error term to test stock type differences, but
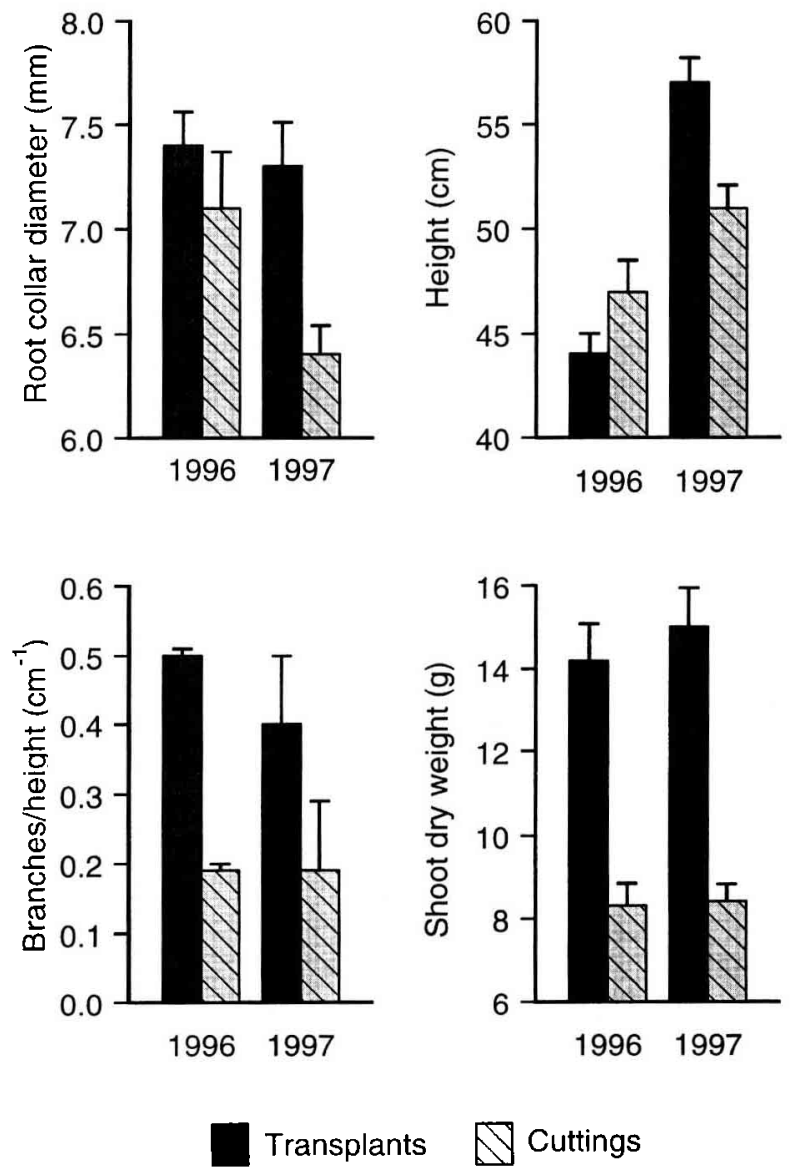

Figure 1. Root collar diameter, height, number of second-order branches $/ \mathrm{cm}$, and shoot dry weight of rooted cuttings and transplants of Sitka spruce. Means are based on 60 plants of each stock type each year. The vertical lines indicate $+1 \mathrm{SE}$.

this effect was not significant. Means by planting date were compared further using the Student-NewmanKeuls' test [51].

\section{RESULTS}

\subsection{Morphology}

There were highly significant differences $(P<0.01)$ between cuttings and transplants for most morphological variables, except for root collar diameter, height and weight of fibrous roots in 1996 (figures 1 and 2). In general, the values for the cuttings were a little more consis- 

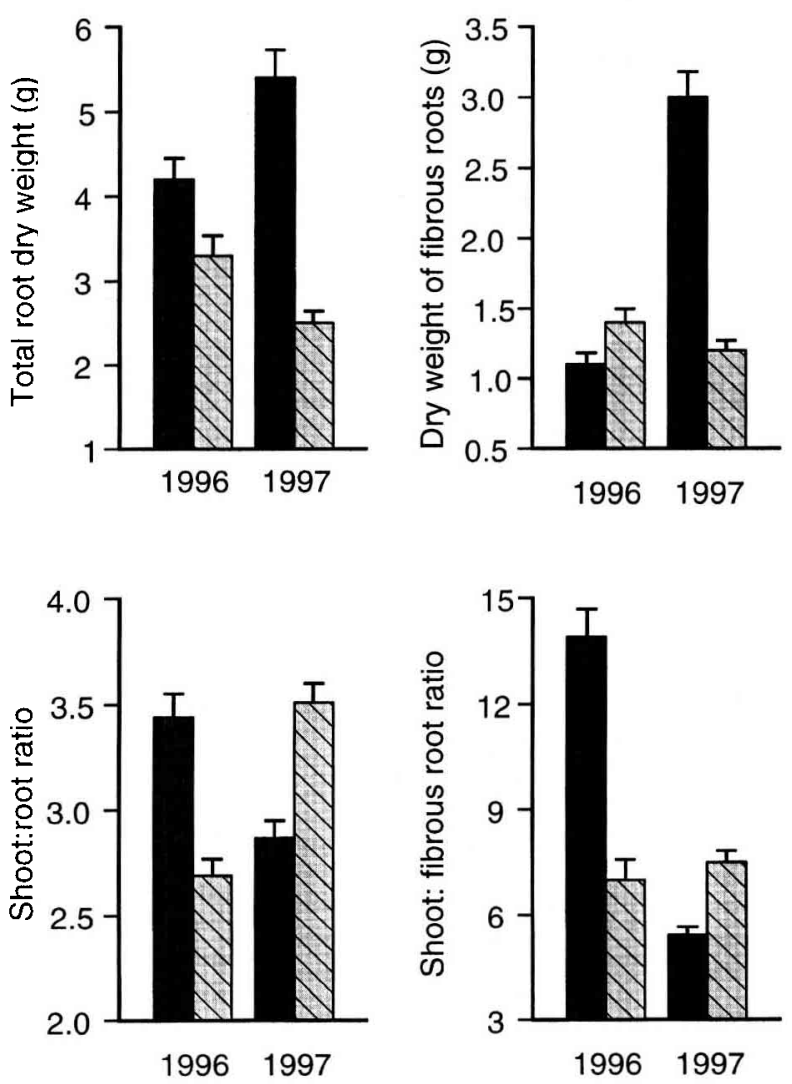

Transplants

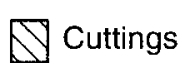

Figure 2. Total root and fibrous root dry weights, and shoot/root and shoot/fibrous root dry weight ratios of rooted cuttings and transplants of Sitka spruce. Means are based on 60 plants of each stock type each year. The vertical lines indicate $+1 \mathrm{SE}$.

tent and variation was lower each year, whereas values often changed greatly and variation was greater for the transplants. The transplants had a larger root collar diameter and were taller than the cuttings in 1997. Nevertheless, absolute differences between stock types for most variables were relatively small, except for those described below.

The cuttings had much fewer first- (figure 1) and second-order (data not shown) branches per unit height than the transplants. These values were similar in each year for the cuttings. The shoot dry weight of cuttings was much less than that of transplants, reflecting their smaller size and lower number of branches. The total dry weight of the whole root system was less in cuttings than

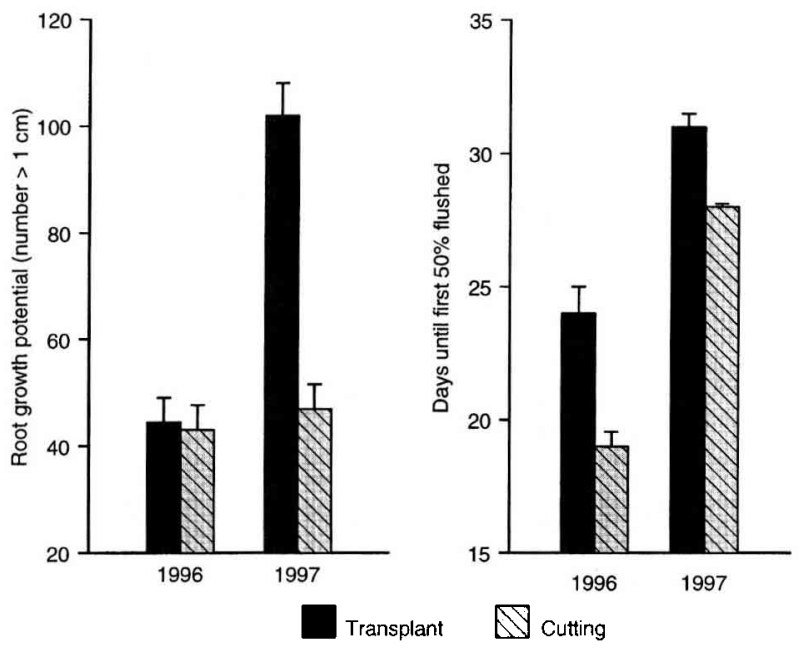

Figure 3. Root growth potential (RGP) and number of days to flushing of cuttings and transplants of Sitka spruce in greenhouse environment. Means are based on 48 seedlings of each stock type in each year. The vertical lines indicate +1 SE.

in transplants, the difference being smaller in 1996 (figure 2). The dry weight of the fibrous roots differed little between stock types in 1996, but much more so in 1997. The cuttings had a more favourable (lower) shoot/root dry weight ratio in 1996, but the reverse was true in 1997. The shoot to fibrous root dry weight ratio also showed the same trend.

\subsection{Root growth potential and days to bud burst in greenhouse}

There was no significant difference in RGP in 1996 , both stock types producing a mean of more than 40 new roots (figure 3 ). The cuttings had a significantly $(P<0.001)$ lower RGP in 1997, however, producing 47 roots compared to 102 roots for the transplants.

The lateral and terminal buds of cuttings flushed significantly $(P<0.01)$ sooner in the greenhouse each year than those of transplants. The difference between stock types for terminal buds was $5 \mathrm{~d}$ in 1996, but only $3 \mathrm{~d}$ in 1997 (figure 4). Nevertheless, under ambient conditions outside the greenhouse, it would take many more days to accumulate equivalent heat sums given that temperatures in the greenhouse were between 15 and $22{ }^{\circ} \mathrm{C}$. 


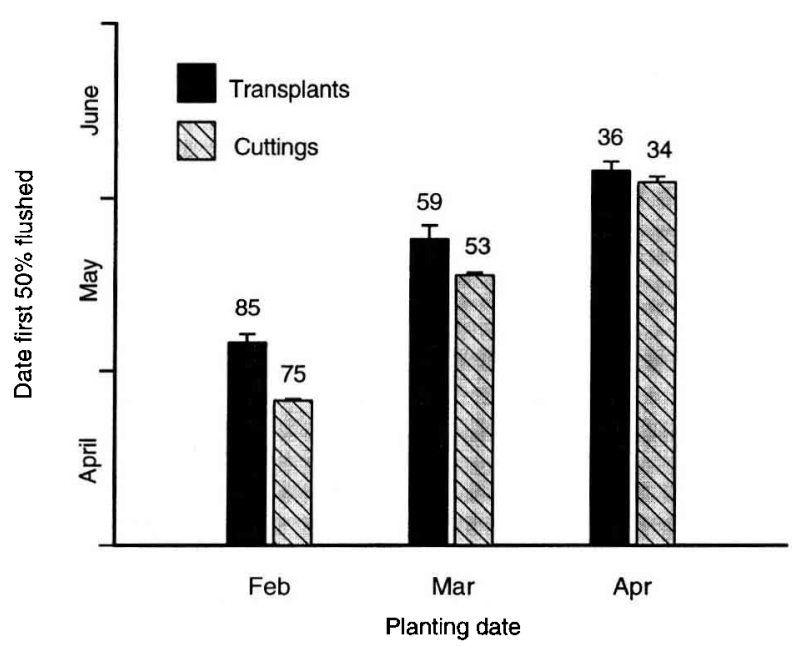

Figure 4. Date of flushing in the field of rooted cuttings and transplants of Sitka spruce in 1997. Seedlings planted in March and April had been cold stored since February. Means are based on four replications of each treatment, each replicate containing approximately 20 plants. The number of days after planting is indicated on each bar. The vertical lines indicate $+1 \mathrm{SE}$.

\subsection{Field growth responses}

There were highly significant differences for the effects of planting date, stock type and the interaction of these factors (all $P<0.001$ ) in the dates of flushing of lateral and terminal buds in 1997. On average the lateral buds flushed before the terminal buds, the difference decreasing the later the planting date, from $14 \mathrm{~d}$ (February) to $7 \mathrm{~d}$ (March) and to $3 \mathrm{~d}$ (April).

Cuttings flushed several days before transplants, the difference being a little larger for lateral buds. The differences between stock types in date of flushing of terminal buds declined with planting date, from $10 \mathrm{~d}$ for February to $2 \mathrm{~d}$ for April (figure 4). The March and April stock had been cold stored since February.

The percentage height increment of cuttings $(52 \%)$ was significantly greater than that of transplants $(41 \%)$ $(P<0.05)$ (figure 5). Therefore, while the transplants were significantly taller than the cuttings at planting $(P<0.01)$, plant height at the end of the season did not differ significantly between stock types. Planting date had no significant effect on these values.

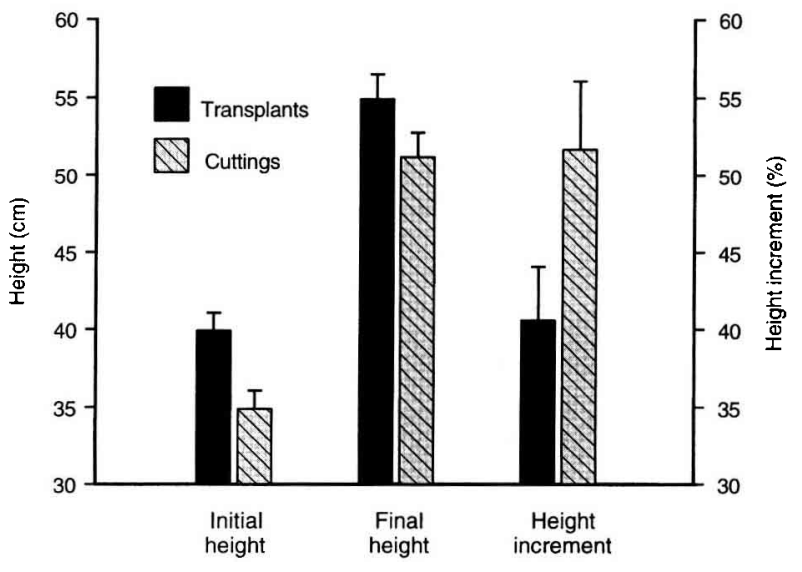

Figure 5. Initial height, final height, and height increment as percentage of initial height of rooted cuttings and transplants of Sitka spruce in the field in 1997. Means are based on four replications of each treatment, each replicate containing approximately 20 plants. Because the effects were not significant, means were taken across all planting dates (three dates $x$ four replications). The vertical lines indicate $+1 \mathrm{SE}$.

\section{DISCUSSION}

Differences between cuttings and transplants for most morphological variables were relatively small from a biological or operational perspective. Therefore, high quality rooted cuttings of Sitka spruce, comparable in quality to 3-year-old transplants, can be produced in 2 years. Furthermore in the field trial, height increment as a percentage of initial height was superior in the cuttings compared with the transplants.

Although the quality of the cuttings was good, there were some interesting differences in morphology, RGP and flushing responses in the greenhouse tests and in the field trial, and some of these may be of operational significance.

\subsection{Morphology, root growth potential}

The cuttings and transplants were of similar root collar diameter in 1996, but the cuttings were slightly smaller in 1997. In all cases, the diameters relative to height of both stock types exceeded the minimum required by EU regulations (Forest Reproductive Material (Amendment) Regulations, 1977 (SI 1977/ 1264)) [1]. 
The cuttings were consistently less heavily branched, however, producing about half the number of first-order branches/cm than transplants (figure 1). Total shoot dry weight was correspondingly smaller in the cuttings. Similarly, branch numbers were smaller in cuttings than in seedlings of Douglas fir [41], and in Norway spruce [19]. The light branching habit is probably an effect of phase change or ageing. Branching behaviour is known to be influenced by plant age and/or maturation $[12,15]$. A decline in branch numbers with age in grafted material has been found for Douglas fir [38], Larix laricina (Du Roi) K. Koch [16] and loblolly pine [14]. Age effects on Sitka spruce needle morphology have been reported [45], and a similar response might be expected for branching characteristics.

The ability of Sitka spruce to expand its foliage surface area rapidly by branching during the juvenile phase of growth is a major contributor to the rapid growth of the species [7]. From the results presented here (figures 1 and 2), it might be speculated that cuttings have a lower potential to rapidly expand their crown during early establishment. Therefore, measurements taken during early field growth may underestimate the growth potential of cuttings because it may take them longer to build up a large photosynthetic surface area. If the light branching habit persists into maturity, it might indicate that a better allocation of dry matter to the stem is taking place. It may be possible to grow more trees per unit area for this reason. The cuttings may also have better stem quality (fewer knots), producing higher value trees [44].

Root dry weight was generally lighter in cuttings than in transplants. It may be possible to increase the root mass in cuttings by increasing the number of first-order lateral roots produced while the plants are in the rooting beds. Following this treatment, specific nursery root cultural practices (e.g. undercutting at shallow depth) may also be necessary to encourage the development of a large root system. Nevertheless, perhaps fortuitously because of the light branching habit, the shoot/root dry weight ratio in cuttings was generally good (figure 2 ). A shoot/root ratio of $3: 1$ is considered acceptable for most planting stock [1]. The transplants exceeded this figure in 1996, while the cuttings did so in 1997, but differences were generally small. It is likely that small year to year variations in growing conditions and cultural practices are reflected in these shoot/root ratio variations.

The RGP of the cuttings and transplants was similar in 1996 and 1997 ([43, 47], respectively), but was greater in the transplants in 1997 [45, 102]. The transplants had a larger fibrous root system than the cuttings in 1997 (figure 2), perhaps contributing to their higher RGP. RGP is sensitive to root mass [42]. Nevertheless, the RGP of the cuttings was good when compared with data on file (O'Reilly et al., unpublished). Improvements in the rooting protocols and root cultural practices in the nursery may lead to an improvement in RGP, as mentioned for root mass above.

\subsection{Flushing response and field performance}

Perhaps the most interesting outcome of this study was the observation that the cuttings flushed earlier than the transplants in the greenhouse tests each year, supporting the findings of the preliminary study [27]. Furthermore, the field trial in 1997 confirmed that flushing differences could occur in the field, although differences were small for those planted latest (see below). No published information could be found to corroborate this finding for Sitka spruce.

The earlier flushing of the cuttings compared with the unimproved transplants is probably largely a result of using plants derived from juvenile selections, although propagation method may also be a factor. Flushing date is probably correlated with height growth in juvenile Sitka spruce, but there is no evidence to support this claim. Others have found no significant relationship between date of bud break and growth among clones of Sitka spruce, although the clones were not selected on the basis of juvenile performance $[3,11]$. In another study [8], height growth was correlated with the length of the growth period in juvenile Sitka spruce, but this was mainly due to the longer period of sylleptic growth in fast-growing trees. In one study of Norway spruce, selection for vigour in 4-year-old transplants was associated with slightly earlier flushing at age 22 in cuttings derived from these plants but not with vigour at age 4 [23]. In another study of Norway spruce using rooted cuttings derived from juvenile selections in the nursery, flushing date was not consistently correlated with growth [17]. The relationship between flushing date and growth rate in trees in other studies was also not consistent [30-32].

The difference in flushing dates between stock types in the field was largest for those planted soon after lifting in February, compared with those planted following cold storage from February to March or April. This result is not surprising because flushing date is heavily influenced by temperatures $[11,24,33]$, and the time difference would be reduced as temperatures increase in the spring. However, the results confirmed that flushing differences (although declining) persisted despite the extra chilling received in the cold store for those planted in February and March. While cold storage would be expected to delay flushing in both stock types (figure 4) 
[39], it also provides extra chilling which may reduce the response differences $[4,5,9]$.

The tendency for cuttings derived from juvenile selected material to flush earlier than transplants suggests that some caution should be exercised in their deployment. Cuttings should probably be planted on low frost risk sites only. Spring frost damage is a common problem for Sitka spruce grown in Ireland and Britain, and for this reason it has been the focus of several studies $[6,10,11]$. Further studies are needed to determine if these differences persist after the first year in the field.

In addition to genetic factors, differences in propagation method may have contributed to the flushing response differences. As mentioned for branching behaviour, differences in physiological age or origin of cuttings as lateral branches may be additional factors. The cuttings originated from lateral shoots, and lateral buds in trees of most species flush earlier than the terminal buds [29] (figure 4). Cuttings often display growth characteristics similar to those of lateral shoots (e.g. plagiotropism) [49], so also might be expected to have a flushing response similar to branches.

Differences in the dormancy cycle between cuttings and transplants, especially dormancy release, may also be a factor, but this cannot be confirmed. In loblolly pine, grafts from older ortets ceased growth earlier than those from younger ortets (all grafts same size) [14], and therefore might be expected to enter dormancy early. Most shoot growth in mature (cuttings) trees of most members of the Pinaceae is proleptic, and therefore growth cessation is likely to occur earlier $[22,28,50]$, and perhaps also flush earlier.

Although smaller at planting, the percentage height increment of cuttings was greater than that of transplants. This result supports the view that cuttings derived from juvenile selections will in the long-term outperform conventional unimproved planting stock. The earlier flushing of cuttings may have allowed them to better exploit the growing season, perhaps contributing to the height increment advantage.

Although the RGP of the transplants was better than that of the cuttings in 1997, this advantage was not reflected in field performance, where in fact the cuttings performed best. The RGP of both stock types was probably sufficient to allow good growth in the field, and RGP probably differed less when adjusted for differences in shoot dry weight. Nevertheless, the cuttings may be more susceptible to handling damage than the transplants given their lower root growth potential in 1997 [46], but this was not examined here.

Acknowledgements: We are grateful to Marianne Lyons, who carried out most of the work in 1996, and to
Joseph Murray, who carried out the preliminary study in 1995 (data not shown). Thanks to R. O'Haire of UCD for his assistance in the greenhouse tests. The assistance of the following Coillte Teo. personnel is also acknowledged: J. Fennessy, R. Lowe, P. Peters, P. Donelin and E. Whelan. Special thanks to D. Thompson, Coillte Teo. for suggesting the study and other assistance provided in carrying out the work. B. Généré (Cemagref, Nogentsur-Vernisson, France) translated the abstract.

\section{REFERENCES}

[1] Aldhous J.R., Nursery policy and planning, in: Aldhous J.R., Mason W.L. (Eds.), Forest Nursery Practice, Br. For. Comm. Bull. 111 (1994) 1-12.

[2] Burdett A.N., New methods for measuring root growth capacity: their value in assessing lodgepole pine stock quality, Can. J. For. Res. 9 (1979) 63-67.

[3] Cahalan C.M., Provenance and clonal variation in growth, branching and phenology in Picea sitchensis and Pinus contorta, Silvae Genet. 30 (1981) 40-46.

[4] Campbell R.K., Regulation of bud-burst timing by temperature and photoregime during dormancy, in: Hollis C.A., Squillace A.E. (Eds. and compilers), Physiological and Genetical Implications of Forestry on Difficult Sites, Proc. 5th N. American Forest Biology Workshop, March 1978, School Forest Resources and Conservation, Univ. Florida, Gainesville, Florida, 1978, pp. 19-33.

[5] Campbell R.K., Sugano A.I., Phenology of bud burst in Douglas fir related to provenance, photoperiod, chilling, and flushing temperature, Bot. Gaz. 136 (1975) 290-298.

[6] Cannell M.G.R., Spring frost damage on young Picea sitchensis 1 . Occurrence of damaging frosts in Scotland compared with western North America, Forestry 57 (1984) $159-175$.

[7] Cannell M.G.R., Photosynthesis, foliage development and productivity of Sitka spruce, Proc. R. Soc. Edinburgh 93B (1987) 61-73.

[8] Cannell M.G.R., Johnstone R.C.B., Free or lammas growth and progeny performance in Picea sitchensis, Silvae Genet. 27 (1978) 248-254.

[9] Cannell M.G.R., Smith R.I., Thermal time, chill days and prediction of budburst in Picea sitchensis, J. Appl. Ecol. 20 (1983) 951-963.

[10] Cannell M.G.R., Smith R.I., Spring frost damage on young Picea sitchensis 2. Predicted dates of budburst and probability of frost damage, Forestry 57 (1984) 177-197.

[11] Cannell M.G.R., Murray M.B., Sheppard L.J., Frost avoidance by selection for late budburst in Picea sitchensis, $\mathrm{J}$. Appl. Ecol. 22 (1985) 931-941.

[12] Fisher J.B., Tree architecture: relationships between structure and function, in: White R.A, Dickison W.C. (Eds.), Contemporary Problems in Plant Anatomy, Academic Press, Orlando, FL, 1984, pp. 541-589. 
[13] Foster G.S., Growth and morphology of rooted cuttings and seedlings of loblolly pine and their genetic analysis, in: Worrall J.L., Dinkins L., Lester D.P. (Eds.), Physiology and Genetics of Reforestation, Proc. 10th N. American Forest Biology Workshop, July 1988, University British Columbia, Vancouver, BC, 1988, pp. 67-78.

[14] Greenwood M.S., Phase change in loblolly pine/shoot development as a function of age, Physiol. Plant. 61 (1984) $518-522$.

[15] Greenwood M.S., Hutchison K.W, Maturation as a developmental process, in: Ahuja M.R., Libby W.J. (Eds.), Clonal forestry I: Genetics and Biotechnology, SpringerVerlag, Berlin, 1993, pp. 14-33.

[16] Greenwood M.S., Hopper C.A., Hutchison K.W., Maturation in larch: 1. Effect of age on shoot growth, foliar characteristics, and DNA methylation, Plant Physiol. 90 (1989) 406-412.

[17] Högberg K.-A., Karlsson B., Nursery selection of Picea abies clones and effects in field trials, Scand. J. For. Res. 13 (1998) 12-20.

[18] John A., Mason B., Vegetative propagation of Sitka spruce, Proc. R. Soc. Edinburgh 93B (1987) 197-203.

[19] Kleinschmit J., Verleichende Wurzeluntersuchungen an Fichtensämlingen und Fichtenstecklingen, For. Arch. 49 (1978) 69-74 (in German, English summary).

[20] Kleinschmit J., Use of spruce cuttings in plantations, in: Rook D.A. (Ed.), Super Sitka for the 90s, Br. For. Comm. Bull. no 103, 1992, pp. 1-10.

[21] Kleinschmit J., Svolba J., Untersuchungen über die Struktur von Fichtenstecklingen. Allgemeine Forst und Jagdzeitung 181 (1980) 147-152 (in German, English summary).

[22] Kramer P.J., Kozlowski T.T., Physiology of Woody Plants, Academic Press, Orlando/London, 1979.

[23] Larsen A.B., Wellendorf H., Rouland H., Realized correlated responses at late stage from upward, downward, and stabilizing selection at nursery stage in Picea abies (L) Karst., For. Gen. 4 (1997) 189-199.

[24] Lavender D.P., Environment and shoot growth of woody plants, Forest Research Laboratory Research Paper no. 45, Oregon State University, Corvallis, OR, 1981.

[25] Mason W.L., Production of bare-root seedlings and transplants, in: Aldhous J.R., Mason W.L. (Eds.), Forest Nursery Practice, Br. For. Comm. Bull. 111 (1994) 84-103.

[26] Mason W.L., Jinks R.L., Vegetative propagation, in: Aldhous J.R., Mason W.L. (Eds), Forest Nursery Practice, Br. For. Comm. Bull. 111 (1994) 135-147.

[27] Murray J.B., The morphology and root growth potential of rooted cuttings compared with transplants of Sitka spruce (Picea sitchensis (Bong.) Carr.), B.Agr.Sci. final year elective project, University College Dublin, 1995.

[28] Nienstaedt H., Dormancy and dormancy release in white spruce, For. Sci. 12 (1966) 374-383.

[29] Nienstaedt H., Genetic variation in some phenological characteristics of forest trees, in: Lieth H. (Ed.), Phenology and
Seasonality Modelling, Springer-Verlag, New York, 1974, pp. 389-400.

[30] Nienstaedt H., Inheritance and correlations of frost injury, growth, flowering, and cone characteristics in white spruce, Picea glauca (Moench) Voss, Can. J. For. Res. 15 (1985) 498-504.

[31] Nienstaedt H., King J.P., Breeding for delayed budbreak in Picea glauca (Moench) Voss: potential frost avoidance and growth gains, in: Proc 2nd World Consultation Forest Breeders, Washington, DC, Part 1, 1969, pp. 61-80.

[32] O'Reilly C., Parker W.H., Vegetative phenology in a clonal seed orchard of Picea glauca and Picea mariana in northwestern Ontario, Can. J. For. Res. 12 (1982) 408-413.

[33] Owens J.N., Molder M., Langer H., Bud development in Picea glauca. I. Annual growth cycle of vegetative buds and shoot elongation as they relate to date and temperature sums, Can. J. Bot. 55 (1977) 2278-2745.

[34] Ritchie G.A., Assessing seedling quality, in: Duryea M.L., Landis T.D. (Eds.), Forest Nursery Manual: Production of Bareroot Seedlings, Martinus Nijhoff/Dr W Junk, Publ., The Netherlands, 1984, pp. 243-259.

[35] Ritchie G.A., Integrated growing schedules for achieving physiological uniformity in coniferous planting stock, Forestry Suppl. 62 (1989) 213-227.

[36] Ritchie G.A., The commercial use of conifer rooted cuttings in forestry: a world overview, New Forests 5 (1991) $247-275$.

[37] Ritchie G.A., Dunlap J.R., Root growth potential: its development and expression in forest tree seedlings, N. Z. J. For. Sci. 10 ( 1980) 218-248.

[38] Ritchie G.A., Keeley J.W., Maturation in Douglas fir: I. Changes in stem, branch and foliage characteristics associated with ontogenetic ageing, Tree Physiol. 14 ( 1994) 1245-1259.

[39] Ritchie G.A., Roden J.R., Kleyn N., Physiological quality of lodgepole pine and interior spruce seedlings: effects of lift date and duration of freezer storage, Can. J. For. Res. 15 ( 1985) 636-645.

[40] Ritchie G.A., Tanaka Y., Duke S.D., Physiology and morphology of Douglas fir rooted cuttings compared to seedlings and transplants, Tree Physiol. 10 (1992) 179-194.

[41] Ritchie G.A., Duke S.D., Timmis R., Maturation in Douglas-fir: II. Maturation characteristics of genetically matched Douglas fir seedlings, rooted cuttings and tissue plantlets during and after 5 years of field growth, Tree Physiol. 14 (1994) 1261-1275.

[42] Rose R., Carlson W.C., Morgan P., The target seedling concept. in: Rose R., Campbell S.J., Landis T.D. (Eds.), US Dept. Agr., For. Serv. Gen. Tech. Rep. RM-200, 1990, pp. 1-8.

[43] SAS, SAS/STAtß User's guide, Version 6, 4th ed., SAS Institute Inc., Cary, NC, 1990.

[44] Spencer D.J., Increased yields of high quality veneer and sawn timber from cuttings of radiata pine, Aust. For. 50 (1987) 112-117.

[45] Steele M.J., Coutts M.P., Yeoman M.M., Developmental changes in Sitka spruce as indices of physio- 
logical age. I. Changes in needle morphology, New Phytol. 113 (1989) 367-375.

[46] Tabbush P.M., Silvicultural principles for upland restocking, Br. For. Comm. Bull. 76, 1988.

[47] Talbert C.B., Ritchie G.A., Gupta P., Conifer vegetative propagation: an overview from a commercialization prespective, in: Ahuja M.R., Libby W.J. (Eds.), Clonal Forestry I: Genetics and Biotechnology, Springer-Verlag, Berlin, Heidelberg, 1993, pp. 145-181.

[48] Thompson B.E., Seedling morphological evaluation what you can tell by looking, in: Duryea M.L. (Ed.), Evaluating Seedling: Quality Principles Procedures and
Predictive Abilities of Major Tests, Workshop Proc., October, 1984, Forest Research Laboratory, OSU, Corvallis, OR, 1985, pp. 59-71.

[49] Thompson D.G., Pfeifer A.R., Future options for genetic improvement of conifers. Part I. Current and near-term technologies. Irish For. 49 (1992) 27-39.

[50] von Wühlisch G., Muhs H.-J., Influence of age on sylleptic and proleptic free growth of Norway spruce seedlings, Silvae Genet. 35 (1986) 42-48.

[51] Zar J.H., Biostatistical Analysis, Printice-Hall Inc, New Jersey, 1996. 